Meta

Journal des traducteurs

Translators' Journal

\title{
Word Order and the First Person Singular in Portuguese and English
}

\section{Belinda Maia}

Volume 43, numéro 4, décembre 1998

L'approche basée sur le corpus

The Corpus-based Approach

URI : https://id.erudit.org/iderudit/003539ar

DOI : https://doi.org/10.7202/003539ar

Aller au sommaire du numéro

Éditeur(s)

Les Presses de l'Université de Montréal

ISSN

0026-0452 (imprimé)

1492-1421 (numérique)

Découvrir la revue

Citer cet article

Maia, B. (1998). Word Order and the First Person Singular in Portuguese and English. Meta, 43(4), 589-601. https://doi.org/10.7202/003539ar
Résumé de l'article

Cet article analyse la fréquence et la nature du modèle de phrase SVO en anglais et en portugais, à partir d'une perspective de linguistique constrastive, particulièrement dans les cas où le sujet est réalisé par les pronoms de la première personne I et eu ou par un nom propre. 


\title{
WORD ORDER AND THE FIRST PERSON SINGULAR IN PORTUGUESE AND ENGLISH
}

\author{
BELINDA MAIA \\ Universidade do Porto, Porto, Portugal
}

\begin{abstract}
Résumé
Cet article analyse la fréquence et la nature du modèle de phrase SVO en anglais et en portugais, à partir d'une perspective de linguistique constrastive, particulièrement dans les cas où le sujet est réalisé par les pronoms de la première personne I et eu ou par un nom propre.

Abstract

From the perspective of contrastive linguistics, this article analyses the frequency and nature of the SVO sentence structure in English and Portuguese, particularly in those cases where the subject is realised by the first person pronoun I and eu respectively or by a name.
\end{abstract}

\section{INTRODUCTION}

The idea that the order in which human languages choose to present information for communication both conditions that communication, and gives us clues to the "natural" order of thought, has been around in various forms for at least a couple of millennia. Nowadays, this interest has been renewed in the search for language universals that may provide clues to how the brain works. Since English and French, two of the most influential languages in recent Western culture, can be described as SVO languages, or languages in which the normal order of an affirmative sentence is that of subject + verb + object, many speakers of these languages have assumed that such an order is the most "natural" and "logical" one.

According to Greenberg (1966: 76-80), this order is, in fact, more widespread than other combinations, with the SOV order coming a close second, and the VSO order "a definite minority." Therefore, he states, "This means that the nominal subject precedes the verb in a large majority of the world's languages." He also claims that "All languages with dominant VSO order have SVO as an alternative or as the only alternative basic order." The bias towards an SVO analysis has influenced the development of grammars in various languages, and efforts have been made to show that this order also underlies all apparently deviant structures.

Many linguists, including Chomsky (1988), treat SVO structures as the norm and, when a nominal subject is present, I would not contest this as the norm. However, in languages that have clearly inflected verbal systems, like Portuguese and other Romance languages, the subject of the sentence is often only present in the inflection of the verb, and the resulting structure could be described as a V+sO order. Moreover, I will argue here that the kind of quantitative analysis electronic corpora makes possible suggests that this structure is sufficiently frequent in natural language usage to be considered as rather more than just an abbreviation or a transformation of the basic SVO order. The reasons for this are probably better understood from a pragmatic that syntactical point of view.

Meta, XLIII, 4, 1998 
This pragmatic perspective becomes clearer when a comparison is made between original texts in two languages and their respective translations. In order to demonstrate this point, I first examined the use of the first person and other pronouns in a Portuguese novel and its English translation, and compared the frequency with which they appeared. ${ }^{1}$ I then compared these results with those taken from an English novel and its translation. ${ }^{2}$ These novels were chosen because they contained a large number of natural monologues and dialogues. This allowed an insight into near-speech type usage and, thanks to the availability of translation corpora, it was possible to compare the linguistic representation of the same situation in two languages.

\section{SUBJECT, THEME AND TOPIC}

The quantitative analysis of texts attempted here, in which the focus is the first person singular in English and Portuguese, not only calls into question the idea that the SVO structure is primary in Portuguese, but shows that Halliday's distinction between Subject, Theme and Topic allows a different psychological interpretation to be made of normal usage in Portuguese.

As Halliday (1985: 32) remarks, the concept of a Subject is "basic to the Western tradition of grammatical analysis." However, the nature and function of the Subject has not always been as clear to grammarians as it apparently is to those of us who have been educated to consider the idea of basic clause patterns, with a subject and predicate, as essential to an understanding of syntax. The Subject has been seen not just in this limited syntactic light but also as the "concern of the message" and the "doer of the action." Halliday re-defines these nineteenth century concepts of Subject as those of Theme, Subject and Actor, (1985: 36-37) as:

i) The Theme is a function in the CLAUSE AS MESSAGE. It is what the message is concerned with: the point of departure for what the speaker is going to say. ii) The Subject is a function of the CLAUSE AS AN EXCHANGE. It is the element that is held responsible: in which is vested the success of the clause in whatever is its particular speech function.

iii) The Actor is a function of the CLAUSE AS REPRESENTATION (of a process). It is the active participant in the process: the one that does the deed.

According to this theory, (ii) is the syntactic Subject familiar to users of modern grammars, and (iii) is the semantic case sometimes described as Actor or Agent, but (i) is rather more controversial. In most unmarked English sentences, it is actually normal for all three roles to coincide, and (ii) and (iii) coincide when the lexical verb requires an Agentive role for its Subject. However, Halliday (1985: Ch. 3) goes to some lengths to show that the Theme is whatever comes first in the sentence, whatever its syntactic or semantic function. Not everyone would agree with him on this point, but I shall not go further into that debate here. ${ }^{3}$

A further notion which is used in discourse analysis is that of "topic."4 This is generally understood to mean whatever we are talking about or, as we often say in everyday English, the "subject" of the conversation. There are various techniques in discourse analysis for establishing the topic, but it is not easy, and a lot depends on the presuppositions and shared knowledge of those involved in the communication. However, in English, it can often be seen to coincide with the Theme or Subject. Other languages, like Chinese, would seem to introduce the topic into their speech in a way which is independent of the Theme or Subject, and which allows the topic to be maintained over several sentences, or until a new topic is introduced, ${ }^{5}$ and Japanese marks it with 
the postposition $-w a .{ }^{6}$ I would suggest that this notion should be taken into account when discussing the first person pronoun and text structure in Portuguese.

\section{THE PRONOUNS EU AND $I$}

\subsection{Anthropological and Psychological Treatment of Pronouns}

The notion of self would seem to be universal, and some, like Popper and Eccles (1977), claim that what distinguishes humanity from the rest of the animal world is "self-consciousness." Steiner (1992: 101) states that "No language has been found to lack a first- and second-person singular pronoun." However, as anyone but an uninformed monolingual will know, the ways in which different languages and cultures actually organize these basic distinctions tend to vary considerably, as Mühlhäusler and Harré (1990) show in some detail.

Myers (1986) discusses claims that the emergence of a strong notion of self is a late development in human culture, but shows how selfhood is well developed among certain Australian aborigines. He suggests that it exists in conjunction with, and as a necessary counterpart to, a desire for relatedness with others which is "reflected powerfully in the concern individuals show to complete themselves through identity with others" (1986: 178). However, there is a fair amount of anthropological evidence, a recent example of which is Lutz (1988), to suggest that in nomadic and rural societies the interests of the self are subordinated to those of the community. It is only natural that this attitude should be reflected in the language.

The function of the first person pronoun has been the subject of much debate in philosophy and psychology, ${ }^{7}$ and the ways different cultures and their languages have chosen to focus the idea of self vary considerably. Most of us will remember the type of pidgin speech in books and films, in which the speaker refers to himself by his proper name rather than by the first person pronoun. However, it would be interesting to know if, why, and how far this reference to the proper name rather than the first person pronoun reflects the native language tendencies of the speaker, or the expectations of the Western anthropologist. As every mother knows, children also go through a phase of referring to themselves by their names as well as $I$, and there is a certain interest in showing a connection between the phylogenetic and ontogenetic development of language, as Mühlhäusler and Harré (1990: Chap. 10) explain.

However, one does not need to compare European to more exotic languages to find differences. ${ }^{8}$ The English-speaking world accepts constant reference to $I$ when discussing an event in which the speaker is involved as perfectly normal, but speakers of other languages, including Portuguese, ${ }^{9}$ would find such a practice both linguistically redundant and socially boorish.

\subsection{The Function of the Pronoun}

The communicative function of pronouns is to simplify dialogue and to make structures more economical. They form part of the reference system described by Halliday and Hasan (1976) and, almost by definition, are among the Given aspects of discourse discussed by Halliday (1985) or those described as Hearer-old, Discourse-old by Birner(1994), at least as far as English is concerned. The first person pronoun is arguably the most obvious Given or Hearer-old element of discourse. It refers to the speaker or writer, or to the speaker + others when in the plural and, at least in English and Portuguese, there is no other normally acceptable way of referring to oneself. ${ }^{10}$ 


\subsection{Omission of the Pronoun}

When linguists construct examples to prove their points, they tend to use proper names, the favourites being John and Mary. ${ }^{11}$ This practice may seem just an attempt at contextualising sentences that otherwise perform in a vacuum, and for dispensing with any previous information in a context implied by the use of pronouns. It also draws attention to the need for a subject to act in an SVO sentence. English speakers may not notice this point because proper names and pronouns are equally necessary before the verb in English.

The economy in language produced by reference can be carried a step further by ellipsis. In English one can describe more than one action performed by a person and only use the pronoun once, as in:

1) I give the priest money, and wink as I kiss the bishop's hand. (Ang. 23) ${ }^{12}$

Here the $I$ before wink has been elided. ${ }^{13}$ However, apart from this sort of example, the use of the pronoun is as obligatory as any other subject with a verb structure in English.

In Portuguese, however, although pronouns exist and can function before the verb, their usage in actual context is marked because the inflection of the verb form usually indicates which person is being referred to anyhow, and to ascribe the usual absence of the pronoun in context to simple ellipsis is to avoid the issue.

Chomsky (1988) discusses the uses of pronouns with verbs particularly dative and reflexive verbs in Spanish, but he also describes the absence of pronouns with verbs in Spanish, and calls this phenomena a case of "empty pronouns." For example, he understands the Spanish creo as I-believe rather than believe-I (1988: 109). If one is arguing for the existence of a subject pronoun at a deeper level, this can be established by describing its disappearance at the surface level in terms of redundancy, when the verb inflection acts as a subject marker, or of inflection + ellipsis, leading to what Chomsky (1988: 90-1) calls "empty categories." He finds them "particularly interesting" but suggests that the computations involved "are part of the fixed structure of the mind/brain" and "it is fair to suppose that they take place virtually instantaneously and of course with no conscious awareness and beyond the level of possible introspection."

This interpretation is the natural one for anyone who is searching for underlying universals, and who assumes that the natural order of sentences is SVO. Besides, as will immediately be pointed out, when Spanish, or Portuguese, sentences function with a nominal as subject, they usually obey the rules typical of SVO sentences, and most authorities ${ }^{14}$ seem to accept these languages as SVO ones. For example, even Ambar (1992), whose work describes subject-verb inversion in Portuguese, only really considers this problem in situations with nominal subjects.

Although I by no means contest the findings of linguists such as Chomsky, nor do I deny the importance of the SVO structure, I should like to draw attention to the data from the corpus which is detailed in tables 1 and 2. These tables are based on the number of personal subjects given in the English versions. We can presume they represent the majority of the clauses requiring such a subject, although the examples which disappear through ellipsis in the English versions are not accounted for here. The number of personal subjects, explicit and implicit, in the Portuguese versions are unlikely to deviate significantly, since the situations are parallel.

The data show that a personal subject, in the form of a name or a pronoun, is only present in the Portuguese novel at a ratio 1:4 in relation to the English translation, as can be seen in table 1. Table 2, however shows that the ratio of the Portuguese translation to the English novel is only $1: 2,03 .{ }^{15}$ This means that only about $25 \%$ of the sentences which cite personal subjects in the English translation actually required them in 
the Portuguese novel. However, the Portuguese translator of the English novel found it necessary to cite personal subjects in $49 \%$ of the situations. When $I / e u$ is involved, the Portuguese novel uses the pronoun in only $20 \%$ of the situations required by the English translation, but the Portuguese translation requires it in $25 \%$ of the cases, as can be seen in tables 3 and 4 .

$\begin{array}{lccc} & \text { English tr. } & \text { Portuguese novel } & \text { Ratio } \\ \text { NAMES } & 750 & 727 & 1.03: 1 \\ \text { PRONOUNS } & 5404 & 815 & 7: 1 \\ \text { TOTAL } & 6154 & 1542 & 4: 1\end{array}$

Table 1

Frequency of names and pronouns in the Portuguese novel + English translation corpus

$\begin{array}{lccc} & \text { English novel } & \text { Portuguese tr. } & \text { Ratio } \\ \text { NAMES } & 685 & 632 & 1.08: 1 \\ \text { PRONOUNS } & 3731 & 1063 & 3.5: 1 \\ \text { TOTAL } & 4416 & 2174 & 2.03: 1\end{array}$

Table 2

Frequency of names and pronouns in the English novel + Portuguese translation corpus

$\begin{array}{lccc} & \text { English tr. } & \text { Portuguese text } & \text { Ratio } \\ \text { I/eu } & 1514 & 296 & 5: 1\end{array}$

Table 3

Frequency of first person pronouns in the corpus

$\begin{array}{cccc} & \text { English novel } & \text { Portuguese tr. } & \text { Ratio } \\ \text { I/eu } & 1385 & 346 & 4: 1\end{array}$

Table 4

Frequency of first person pronouns in the corpus

The proportions given above would suggest two things:

a) that the apparently subjectless sentence is the norm rather than the exception in natural Portuguese;

b) when the Portuguese text is a translation from English, the SL will influence the TL to include the name or pronoun more often.

In order to understand why this happens, let us now look at the factors which influence the speaker's choice to use or avoid the Portuguese pronoun eu. 


\section{THE USE OF EUIN PORTUGUESE}

The following passages are taken from the Portuguese novel in the corpus:

2a) Ninguém deve odiar, mas eu odeio-o. A ele e a todos os tipos como ele [...] Odeio todos os tipos que comem lagostins sem sujar as mãos. Odeio-os. Se os pudesse matar, matava-os. (Ang. 21)

2b)No one should hate others, but I hate him. Him and all the rest like him. I hate all those who can eat crayfish without getting their hands dirty. I loathe them. And I'd kill them if $\underline{I}$ could. (tr. 15)

It is interesting to notice how $I$ acts as both Subject and Theme of all the English clauses in which it appears, that it has not been elided at all and, for various reasons, cannot be elided. In the Portuguese original, however, eu appears only in the first clause, and even here it is arguable whether it is strictly necessary syntactically, or whether it is introduced out of a pragmatic need to oppose eu to ninguém (no one) in the previous clause for reasons of contrast. In fact, one may well ask whether the $e u$ is acting as Subject or Theme at the level of the clause, and even whether it is a Topic which is carried on over the rest of the text. Although the verb form odeio is marked for the first person subject in the next two clauses, the $e u$ is presumed from the context for pudesse and matava, which could be used with a third person interpretation.

$\begin{array}{lccc} & \text { Total } & \text { pre-Verb } & \text { post-Verb } \\ \text { Unmarked verbs } & 119(40.2 \%) & 106(35.8 \%) & 13(4.4 \%) \\ \text { Marked verbs } & 132(44.6 \%) & 85(28.7 \%) & 47(15.5 \%) \\ \text { Ellipsis } & 32(10.8 \%) & - & - \\ \text { Other } & 13(4.4 \%) & - & - \\ \text { TOTAL } & 296(100 \%) & 191(64.5 \%) & 50(19.9 \%)\end{array}$

Table 5

Analysis of the use of $e u$ in the Portuguese novel

$\begin{array}{lccc} & \text { Total } & \text { pre-Verb } & \text { post-Verb } \\ \text { Unmarked verbs } & 155(43.8 \%) & 126(35.6 \%) & 29(8.2 \%) \\ \text { Marked verbs } & 184(52 \%) & 170(48 \%) & 14(4 \%) \\ \text { Ellipsis } & 13(3.7 \%) & - & - \\ \text { Other } & 2(0.6 \%) & - & - \\ \text { TOTAL } & 354(100 \%) & 296(83.6 \%) & 43(12.2 \%)\end{array}$

Table 6

Analysis of the use of $e u$ in the Portuguese translation

All the sentences in which $e u$ appeared in the Portuguese novel and the Portuguese translation were analyzed according to the following criteria:

a) with verb forms not marked for first person singular, where the primary function of the pronoun is to clarify the syntax; 
b) with verbs marked for first person singular and plural, where the primary function of the pronoun is that of emphasis;

c) in elliptic situations;

d) other: e.g. comparative phrases like como eu (like me).

\subsection{Use of $e u$ to Define the Speaker}

Not all verb forms in Portuguese are unambiguously marked for first or third person, particularly with the "Imperfeito," "Conjuntivo" "Futuro do Pretérito" and infinitive forms and, on these occasions, the $e u$ is used to elucidate the situation, as in:

3) A Teresa aceitou sem um queixume a notìcia de que eu tinha uma amante. ${ }^{16}$ (Ang.24)

4) $\mathrm{O}$ ideal é aprender a não pensar. Que bom seria se eu aprendesse a não pensar. ${ }^{17}$ (Ang. 19)

In these cases one could point to a straightforward SVO clause as the verb does not specify the subject clearly. However, one could also argue that the eu establishes a new theme or topic in the text because the same verb forms can function without the eu when no change of theme or topic is needed, as in:

5) - A tua resposta, Gonçalo, é mais do que elucidativa. Já agora, diz-me: porque manténs estes nossos jantares mensais?

- Tinha-te pedido que respondesses tu. ${ }^{18}$ (Ang. 16)

As one can see in tables 5 and 6 , those examples in which the pronoun occurred with unmarked verb forms accounted for $40.2 \%$ of the examples in the Portuguese and $43.8 \%$ in the Portuguese translation. Although these examples included some which could have been explained in terms of the emphasis of a previously established topic, rather than that of providing a necessary subject, most of them were used for reasons of greater explicitness. The slightly higher explicitness in the Portuguese translation may be due to some peculiarity of style of the translator, but could equally well be explained in terms of the fact that translations tend to be more explicit than originals.

\subsection{Use of eu to Emphasize the Speaker}

The nearest we come to a strictly syntactic use of $e u$ is with those examples described in the previous section, in which the subject is not clear from either the verb form or the context. Whether one considers the appearance of $e u$ here as proof of a syntactic subject, or the introduction of a pragmatic topic, is largely a matter of perspective. However, once the subject is deducible from the context, the eu becomes optional, and it is this optional usage that will be examined here.

The examples where the use of $e u$ could usually be shown to be redundant semantically, but necessary for more pragmatic reasons, accounted for $44.6 \%$ in the novel and 52\% in the translation. Here the margin of difference between the novel and the translation is greater, and the need for the extra emphasis may well have been influenced by the original English where the $I$ would be essential.

The principal reasons for the choice of $e u$ would seem to be emphasis, although most examples can be classified on the gradient between the necessary and the superfluous, and few belong to either end of this gradient. A semantic element underlying a lot of the examples was that of the relationship of the speaker with Another. This is at its most obvious when $e u$ is used with another pronoun, either in conjunction, as in $\underline{T u e}$ $\underline{\text { eu }}$ sabemos que os nossos mundos são diferentes e quase não misturam. ${ }^{19}$ (Ang 15), or in contrast, as in, Uma vez dadas as cartas, o jogo seguirá até que um seja vencido. Ou eu ou ele. ${ }^{20}$ (Ang. 186). 
Several examples classified here can only omit the pronoun if there is a close understanding of the text, as in:

6) Estou a vê-lo [...] Sentado atrás da secretária [...] Já curvado [...] Levantou a cabeça e perguntou-me se eu sabia fazer alguma coisa. Respondi-lhe que era formado em Direito e ele largou a rir e esclareceu que não me tinha perguntado o que eu era mas sim o que $\underline{\text { eu }}$ sabia fazer... ${ }^{21}$ (Ang. 188)

In this example the first $e u$ is possibly necessary to make the subject clear, although the -me partly indicates who is referred to by sabia, and the situation is that of a father-son confrontation. Despite the use of the imperfective, which allows for a certain ambiguity to arise with the interpretation of era and the second sabia, the second and third use of $e u$ could be left out without disturbing the basic understanding of the text. However, it is probably included to emphasize the confrontational atmosphere, by thematising the speaker rather than what he was or what he knew.

The speaker/other relationship is often behind the need to use the pronoun, as can be seen in:

7) Pertences a uma classe em que tudo acaba sempre bem. Até as historias que vos contam em pequenos acabam bem: "casaram, tiveram muitos filhos e foram muito felizes." $\underline{\mathrm{Eu}}$ pertenço a uma classe em que tudo acaba mal. ${ }^{22}$ (Ang. 12)

This relationship is quite clear, either in the sentence, or at the level of contrasting situations, with parallel structures in the text. Sometimes it is used to draw attention to the speaker in contrast with several others already mentioned, even if they are understood only at the level of context, as is the case with the other clerks in the office in the following example:

8) É que vou todos os dias à Avenida do Infante Santo, a um daqueles prédios novos construídos sobre colunas. Mora lá um dos sócios do escritório, que está de cama, e eu vou levar-lhe o expediente todas as tardes. ${ }^{23}$ (Ang. 213)

This fact can only be known if one has read the relevant parts of the book, yet, from the strictly syntactic point of view, the eu could be left out.

There are examples where the $e u$ has been thematised in a way which makes its removal a little difficult. This happens when the thematisation results from a double contrast, as in the following example where there is Another mentioned in the text immediately preceding the sentence, and also further Others implied by the context:

9) - Para que diabo vens tu jantar comigo todos os meses e conservas esta farsa que é a nossa amizade? Eu não posso interessar-te de forma alguma. Nasci na classe dos $2500 \$ 00$ por mês e já atingi a minha craveira. ${ }^{24}$ (Ang. 14-5)

To remove $e u$ here would thematise posso, or the ability of the speaker to do something. Since the fact of interesting the Other, (interessar) depends, in this case, on the psychological processes of the Other rather than the actions of the speaker, ${ }^{25}$ the absence of the $e u$ would produce a particularly awkward sentence.

When the verb is acting intransitively and alone, the thematisation of the pronoun becomes useful to avoid abruptness or impoliteness, as can be seen in with the second occurrence of eu:

10) - Que estopada, Gonçalo! Tive de aturar aquele chato [...] mas que havia eu de fazer? Ele chamou-me $[\ldots]$

- Eu vi. ${ }^{26}$ (Ang. 90)

The second speaker subtly shifts the emphasis onto himself rather than his critical observation of the other's behaviour to alleviate the other's embarrassment. On the 
other hand, in the following example, the busybody speaker betrays his desire to emphasize his personal role in the situation:

12) - Sabe quem eu vi no domingo?

- Não.

-A sua pequena. ${ }^{27}$ (Ang.83)

\section{3. $E U$ in Post-verb Position}

The classification of the examples into pre- and post-verb position proved to be most interesting. It posed interesting questions about the analysis of post-verb position in Portuguese, and it also drew attention to the biggest discrepancy between the Portuguese original and the Portuguese translation.

When one is taught Portuguese as a second language, one is not encouraged to use subject-verb inversion to create questions, especially in spoken Portuguese. However, the analysis of examples from the Portuguese novel showed that such inversion is possible, as in:

13) Como posso eu ser amigo de alguém para quem três whiskies antes de jantar são apenas três whiskies antes de jantar e não uma despesa incomportável? E tu? Como podes tu ser amigo de alguém que já classificaste mentalmente como pertencente à classe dos que não ultrapassam a barreira dos $2500 \$ 00 ?^{28}$ (Ang. 15)

This question type of inversion seems to appear quite naturally after question words like como, que, quanto, and para que, ${ }^{29}$ and occurred quite frequently in the Portuguese novel. The structure is apparently acceptable in a more literary context, but its frequency here may be an idiosyncrasy of the Portuguese author as examples of the structure were not found in the Portuguese translation. This idiosyncrasy is paralleled by the translator's frequent use of inversion with verbs of speech and intellectual process, as in disse eu which was frequently used in situations where said I (accompanying examples of direct speech) would have suitable equivalents in the English original. The Portuguese author does not use this structure.

Other uses of $e u$ after the verb seem to be prompted by a need to emphasize it, despite some previous decision to thematise the verb in the normal way, particularly when the clause is short, and perhaps lacking in content and balance without the addition of the pronoun, as in:

14) Lá estou eu a pensar outra vez no gajo... ${ }^{30}$ (Ang. 48)

15) - Posso ir eu. Digo que sou empregado do construtor. ${ }^{31}$ (Ang. 118)

At other times the $e u$ seems to have been included to give balance to an unusually thematised sentence, as with the following cases of adjectival and object thematisation:

16) Muito bêbedo estou eu. ${ }^{32}$ (Ang. 70)

17) - O que tu queres sei eu, mas não levas nada. O gajo não vem... ${ }^{33}$ (Ang. 112)

In these examples, one could argue that the pronoun is actually omissible from a syntactic point of view, despite the uneven balance of the resulting sentences. Similar structures are also quite frequent in the Portuguese translation, and the best way to describe this usage is as somewhere on the gradient between the necessary and emphatic uses of the pronoun.

The figures for the post-verb position vary quite considerably from the original to the translation, $4.4 \%$ and $8.2 \%$ with verbs not marked for the first person, and $15.5 \%$ and $4 \%$ with marked verbs. This gives totals of $19.9 \%$ and $12.2 \%$ respectively, giving the original a $7.7 \%$ predominance over the translation. As we have seen, however, some of 
these percentages reflected possible idiosyncrasies of the writer or style, and these facts need to be considered alongside others before their real significance can be judged.

\section{4. $E \boldsymbol{u}$ in Situations of Ellipsis, Substitution and in Other Structures}

The original diverged from the translation quite considerably when the pronoun's use could be explained in terms of ellipsis: $10.8 \%$ for the original and $3.7 \%$ for the translation, or 'other' factors, $4.4 \%$ and $0.6 \%$. This reflects an interesting difference of conventions of ellipsis and substitution in the two languages.

One argument that can be used to show that the eu as Subject exists at some level is the fact that it can remain to mark a position when other elements of the communication have been ellipted, as can be seen in the exchange: A) Gosto da sua casa. B) Também eu. ${ }^{34}$ where B's phrase can be seen as a short form of Também eu [gosto da sua casa.]. However, if the speaker wants to emphasize the fact of liking (gostar) rather than his/herself as the liker, the answer could be Também gosto in which the eu is unnecessary. The decision to focus one factor or the other in an ellided construction in Portuguese is, therefore, probably subject to much the same pragmatic factors as other usages of the pronoun.

There are other cases such as in: Só me interessa uma coisa: $\underline{e u}$, in which the pronoun acts independently to express an emphasis only translatable by myself. It can also be used in cases where the speaker is trying to regain control of the conversation by drawing attention to his/herself, as in:

18) - Vista-se e saia.

-Mas Amélia, eu...

-Não me chamo Amélia; o meu nome é Alexandra. ${ }^{35}$ (Ang. 77)

This situation has a parallel in English.

The other uses of $e u$ after the verb seem to occur for various reasons. Sometimes the verb is a copula such as ser (be) and the speaker is describing him/herself in terms which thematise this description rather than the speaker, as in:

19) - Parece-me que a Maria é quem mais trabalha nesta casa...

O porteiro, de pé, com o guardanapo na mão, esclarecera a situação:

- O marido sou eu, Sr. Doutor. ${ }^{36}$ (Ang. 30)

Even so, sometimes the verb is thematised in preference to both $e u$ and the description, as in:

20) - Por enquanto, meu filho, ainda sou eu quem te ajuda. Podes estar certo de que ninguém te ajudará com mais boa vontade e amor. ${ }^{37}$ (Ang. 170)

In these cases, the copular structure makes the $e u$ obligatory.

The main reason why examples of 'other' factors were more frequent in the original than the translation was because of the frequency of examples like como eu, used to contrast the Self with Another, and translatable by as I do or like me: as in Sabes tão bem como eu que..., ${ }^{38}$ (16) or to use eu as an example among others, as in Os hábitos são a única defesa dos gajos como eu. ${ }^{39}$ (78). The eu cannot be omitted or ellided in these examples because they are already acting as the remaining element in an ellipsis situation in which they are the thematised items.

\subsection{The Influence of the English Original on the Portuguese Translation}

If the order in which the elements of a sentence are presented reflects not just syntax but also aspects of thematisation and information flow, it would seem rather inevitable that the syntactic structure of an original text will sometimes influence the 
translation. The examples given here of post-verb position and ellipsis certainly reflect differences between the languages as well as individual idiosyncrasies of the texts. However, where one can see the influence of the normal English order of the sentence on the translation most clearly is in the high percentage of times in which the pronoun appears in pre-verb position, only $64.5 \%$ in the original and $83.6 \%$ in the translation, a difference of $19.1 \%$. It is particularly significant that this is due to the incidence of $e u$ before verbs already marked for the first person, with a difference of $19.3 \%$ between the original and the translation. This can only indicate that the translator was influenced by the obligatory $I$ of the original.

\section{CONCLUSIONS}

There are three points of interest which arise from this short study. The first is related to the question - Is the verb the normal theme of Portuguese sentences? In a world of linguistics which seems convinced of the priority of SVO structures, it may be heretical to suggest that a language which clearly demonstrates that it normally places a nominal acting as subject before a verb should have VSO tendencies, even of the $\mathrm{V}+\mathrm{sO}$ type. I do not dispute the fact that sentences including such a nominal can be considered SVO ones at a syntactic level, providing one disregards the subject marker in the verb on these occasions. However, I do believe that if one reassesses the function of this noun as a theme, and particularly as a topic, the SVO/VSO dichotomy becomes less clear.

The normal absence of pronouns in S position certainly suggests that those items appearing explicitly in the $\mathrm{S}$ position could be re-evaluated either as themes or as topics. This hypothesis is borne out by the fact that the similarity between pronouns was at its highest with $e u / I$, that between other pronouns varying between 1:7 and 1:9 ratios in the original, although the influence of the English version on the translation is more obvious in this area with the variation ranging only from 1:3.6 to 1:9. This would suggest that research into these pronouns would produce even more convincing arguments for both the $\mathrm{V}+\mathrm{s} O$ hypothesis and the suggestion that original texts influence the information structure of the translation.

The second conclusion that can be drawn is related to the whole problem of thematisation and information structure. If viewed from a more pragmatic perspective, the implications of the verb acting as the normal theme of a high proportion of Portuguese sentences cannot be ignored. If the Theme/Rheme theory of discourse proposed by Halliday and others is valid, this phenomenon demonstrates that Portuguese speakers intuitively give more importance to the verbal process than to the person or other entity involved. Even if one condemns this theory as unacceptably Whorfian, one has to accept that the flexibility of word order, and the wider variation of thematisation in Portuguese in relation to English do at least allow for more subtlety in communication.

After all, in English it is difficult to rearrange the sentence I believe that she is right in any plausibly acceptable way. ${ }^{40}$ However, we can choose to translate this sentence using at least three different types of word order, of which the least marked is Creio que ela tem razão, in which we have the normal thematisation of the lexical meaning of the verb, with the subject identified at the end of the word. However, one can place heavy emphasis on the speaker's role at the expense of the mental process of believing by thematising $e u$ and saying Eu creio que ela tem razão. Alternatively, if one still wants to emphasize the lexical meaning of believing first, with the speaker in a scheme of secondary emphasis, one can say Creio eu que ela tem razão. The decision as to which translation we choose will depend on pragmatic circumstances. The first constitutes a 
simple statement, but the second and third take Another's state of belief into consideration. The second translation suggests that the speaker is heavily involved in affirming the belief, and is prepared to defend the opinion whatever the Other believes, but the third is more tentative and gives the impression that the speaker is asserting his/her own belief, but is prepared to accept that the Other may not agree.

Although the psychological implications of this analysis may be hardly earthshattering, and those interested will no doubt seek to prove that the whole $\mathrm{V}+\mathrm{sO}$ phenomenon I discuss here is merely evidence of optional versions of the basic SVO structure, there is a third dimension to this problem which may be important at a cognitive level. The time factor involved in making the necessary transformation may be insignificant, as Chomsky says, especially if one takes the general problem of the time involved in language processing into account ${ }^{41}$ However, one might ask if that fraction of a millisecond is actually employed in making the $\mathrm{SVO}>\mathrm{V}+\mathrm{sO}$ deletion or transformation, or whether the Portuguese speaker, at some stage of his/her linguistic development, may not have internalized a system of economy which allows for this structure as the most natural one, with pragmatic decisions adding the noun or pronoun to the structure of the communication when necessary as subject, theme or topic. After all, the brain will have plenty to do just making these multiple and complex decisions, not all of which are linguistic in nature, as Churchland (1990) demonstrates, and many of which will be influenced by factors buried in the stored information known as our unconscious, which reflects a lifetime of social and psychological experience. The comparison of any text and its translation will provide plenty of evidence of this complexity, as Steiner (1992) demonstrates so well.

The systematic use of parallel and comparable corpora allow one to analyse the complexity of language in context on a quantitative as well as a qualitative basis. The qualitative analysis of the well-informed 'native speaker' often holds good when tested against the quantitative data provided by corpora. However, I hope that I have demonstrated that the relevance of certain structures can only be truly understood after consulting large quantities of 'real' language, whether spoken or written.

\section{Notes}

1. The Portuguese novel and its translation which served as part of the corpus referred to in this article are: MONTEIRO, Luis de Sttau (1961): Angústia para o Jantar, Lisboa, Edições Atica, 49,459 words.

MONTEIRO, Luis de Sttau (1964): The Rules of the Game, (Translation of the above), Translated by Ann Stephens, London, Putnam and Co. Ltd., 55,708 words.

The numbers of words were calculated electronically, and allowances should therefore be made for textual errors.

2. The English novel and its translation which served as part of the corpus referred to in this article are:

FITZGERALD, F. Scott (1925): The Great Gatsby, Electronic version acquired for research purposes from the Oxford Electronic Computing Service.

FITZGERALD, F. Scott (1986): O Grande Gatsby, Translated by José Rodrigues Miguéis, Lisbon, Ed. Presença, Lda.

3. For further analysis of this problem see Langacker (1990: II, Chapter 7), and Baker (1992: Chapter 5).

4. See, for example, Brown \& Yule (1983: Chapter 3).

5. See Baker (1992: 141) on Li, C.N. (1976) "Subject and Topic: a New Typology of Language," in Li, C.N. (Ed.) Subject and Topic. London, Academic Press.

6. See Halliday (1985: 38).

7. See Maia (1994).

8. The study of the network of relations in various societies has been one area in which anthropologists and linguists have worked together, because a clear view of the way these relations work linguistically provides valuable clues as to how the society itself works. Even between two languages that have so much in common as English and Portuguese, there are plenty of differences. Despite the image the Englishman has of being a snob, there are no real hierarchical distinctions built into the pronoun system, and you serves for all normal second-person references. Portuguese, on the contrary, not only makes the distinction between the singular 
$t u$ and the plural vos, but also the distinction between the familiarity implied by their usage, and various degrees of formality inherent in the use of the third person, você, and proper names for effectively referring to the second person. Whether one can ascribe the disappearance of the finer distinctions implied by thou and earlier forms of address in English to some underlying desire for "political correctness" long before the concept was invented, would be an interesting theme to develop. I suspect, however, that such linguistic changes have not succeeded in eliminating the underlying reality of social distinctions, but have simply forced these distinctions to express themselves in different ways, a point which people with high hopes for promoting political correctness might bear in mind.

9. See also Baker (1992: 127) in relation to Spanish and Arabic.

10. For a reflection on this point see Langacker (1990: I, 131)

11. These names have become so institutionalized that one often finds João and Maria in similar situations in Portuguese, when José and Maria might better represent the relative popularity of the names.

12. Numbers in brackets after an example - - e.g. (23) - - indicate the page number of the Portuguese original or English translation on which the example can be found.

13. One can construct more complex examples like the sort of example often quoted for this effect:

I got up, had my bath, cleaned my teeth, had my coffee and left for work.

However, these would appear to be rare in actual communication.

14. For a description of this debate, see Ambar (1992: Chap. 4.1).

15. One often hears rather chauvinistic English speakers claiming that English is a more efficient language because it manages to express the same message in fewer words than languages like Portuguese. As one can see from the word-count for these novels in Note 1, the English text actually exceeds the Portuguese text by the not inconsiderable margin of 6249 words. A quick calculation will show that 4612 , or $73 \%$, of these words can be accounted for by the "missing" names and pronouns.

16. Tr. Teresa accepted the fact that I kept a mistress without a murmur. (18)

17. Tr. I'd better learn to stop thinking. How wonderful if I could learn to stop thinking. (14)

18. Tr. "That answer's most revealing, Gonçalo. Now tell me why do you keep up these monthly dinners?" "I have told you to answer yourself." (12)

19. Tr. You and I both know that our worlds are entirely different, and that they don't mix. (11)

20. Tr. Once the cards have been dealt, the game must go on till one of them is the loser. Either he or the other. (145)

21. Tr. I can see him now [...] sitting behind his desk, already bowed [...] He raised his head and asked me if I could do anything. I told him that I had a degree in Law, and he burst out laughing and explained that he had not asked me what I had, but what I could do. (147)

22. Tr. You belong to a class where everything turns out well. Even the stories you hear when you're young have a happy ending: They married, had lots of children and lived happily ever after. I belong to a class where everything turns out badly. (9)

23. Tr. I go over to Avenida do Infante Santo every day, you see, to one of those new buildings constructed on columns. One of the partners of the firm who lives there is laid up at the moment and I take him his mail every afternoon. (166)

24. Tr. Why the hell do you come and have dinner with me every month and keep up this farce of a friendship? I can't interest you in the least. I was born in the 2,500 escudos a month class and I have already reached my limit. (11)

25. See Maia (1994: Chapter 3).

26. Tr. "What a bore, Gonçalo! I had to put up with that nincompoop. But what else could I do? He called me over..."

"So I saw." (69)

27. Tr. "Guess who I saw on Sunday?"

"No idea."

"Your little girl-friend." (64)

28. Tr. How can I be a friend of someone for whom three whiskies before dinner means simply three whiskies before dinner and not an outrageous extravagance? And you? How can you be a friend of someone whom you have already mentally classified as belonging to the class who'll never get beyond the 2,500 a month limit?(11)

29. A learner of Portuguese would be encouraged to use the structure Como é que (eu) posso... to formulate the question in Ex. 13.

30. Tr. Ah, there I go thinking of that fellow again. (36)

31. Tr. "I can go. I can say I'm working for a builder."(91)

32. Tr. "I am really drunk ..." (53)

33. Tr. "I know what you want all right, but you're not getting that [...] The fellow won't come ...(86)

34. Tr. A) I like his house. B) So do I (or I do, too).

35. Tr. "Dress yourself and get out."

"But Amélia, I..." 
"My name's not Amélia. My name is Alexandra." (59)

36. Tr. "It seems to me, Maria is the one who does the most work in this house ...

"The caretaker rose to his feet, and with napkin in hand, made the position quite clear.

"I'm the husband here, sir." (23)

37. Tr. "For the moment, my boy, it is still I who am in a position to help you, and you can be sure that no one will help you more willingly and with more love." (133)

38. Tr. You know as well as I do that ... (12)

39. Tr. Habits are the only defence for those in the 2,500 a month class. (60)

40. Empty "it" sentences like It is I who believes that she is right, or cleft sentences like That she is right, I believe, appear too rarely outside books on linguistics as to merit consideration here. Any difference of emphasis that could be achieved to match those expressed by word order in Portuguese, can only really be found at the level of intonation. For example, the meaning of second translation could be rendered by placing extra emphasis on I believe in relation to the rest of the sentence, and that of the third by emphasizing just the $I$.

41. The question of time factor involved in the conscious or unconscious processing of information has raised many questions which have been discussed by writers such as the neuroscientist Pöppel (1987) and the physicist Penrose (1990), and there is no doubt it is difficult to solve. However, until some plausible attempt is made to solve it, present theories of time would seem to encourage an approach which sees language as resulting from the simultaneous processing of multiple items of both linguistic and non-linguistic information in the brain, rather than the more linear and logical approaches usually used to prepare artificial intelligence for linguistic communication.

\section{REFERENCES}

AMBAR, Maria Manuela (1992): Para uma Sintaxe da Inversão Sujeito-Verbo em Português, Lisbon, Edições Colibri.

BAKER, Mona (1992): In Other Words, London, Routledge.

BIRNER, Betty (1994): "Information Status and word order", Language, Vol, 70, No 2 June.

BROWN, Gillian \& George YULE (1983): Discourse Analysis, Cambridge, Cambridge University Press.

CHOMSKY, Noam (1988): Language and Problems of Knowledge, Cambridge (Mass.), The MIT Press.

CHURCHLAND, Patricia (1990): Neurophilosophy, Cambridge (Mass.), London, The MIT Press.

GREENBERG, J. H. (1966): "Some Universals of Grammar with Particular Reference to the Order of Meaningful Elements?", J.H. Greenberg (Ed.), Universals of Language, Cambridge (Mass.), The MIT Press.

HALLIDAY, M.A.K. \& Ruqaiya HASAN (1976): Cohesion in English, London, Longman.

HALLIDAY, M.A.K. (1985): An Introduction to Functional Grammar, London, Edward Arnold.

LANGACKER, Ronald W. (1990): Foundations of Cognitive Grammar, Stanford, California, Stanford University Press.

LI, C.N. (1976): "Subject and Topic: a New Typology of Language", C.N. Li (Ed.), Subject and Topic, London, Academic Press.

LUTZ, Catherine A. (1988): Everyday Sentiments on a Micronesian Atoll and their Challenge to Western Theory, Chicago, Chicago University Press.

MAIA, Belinda (1994): A Contribution to the Study of the Language of Emotion in English and Portuguese, Doctoral thesis, Faculdade de Letras, Universidade do Porto.

MONTEIRO, Luis de Sttau (1961): Angústia para of Jantar, Lisboa, Edições Atica.

MONTEIRO, Luis de Sttau (1964): The Rules of the Game, (Translation of the above), Translated by Ann Stephens, London, Putnam and Co. Ltd.

MÜHLHÄUSLER, Peter and Rom HARRÉ (1990): Pronouns and People, Oxford, Blackwell.

MYERS, Fred R. (1986): Pintupi Country, Pintupi Self, Berkeley, University of California Press.

PENROSE, Roger (1990): The Emperor's New Mind - Concerning Computers, Minds and the Laws of Physics, London, Vintage.

PONTES, Eunice (1973): Verbos Auxiliares em Português, Petrópolis, Brazil, Editora Vozes, Ltda.

PÖPPEL, Ernst (1989): Mindworks, Boston/San Diego/New York, Harcourt Brace Jovanovich, Pub.

POPPER, Karl R. \& John C. ECCLES (1977): The Self and Its Brain - an Argument for Interactionism, London, Routledge and Kegan Paul.

QUIRK, Randolph, GREENBAUM, Sidney, LEECH, Geoffrey and Jan SVARTVIK (1985): $A$ Comprehensive Grammar of the English Language, London and New York, Longman.

STEINER, George (1992): After Babel, New edition, Oxford, Oxford University Press. 